\title{
Movement patterns of Atlantic cod in Gilbert Bay, Labrador: evidence for bay residency and spawning site fidelity
}

\author{
John M. Green* and Joseph S. Wroblewski ${ }^{\dagger}$ \\ *Department of Biology, ${ }^{\dagger}$ Ocean Science Centre, Memorial University of Newfoundland, \\ St John's, Newfoundland, AlB 3X9, Canada. *Corresponding author, \\ e-mail: jmgreen@mun.ca
}

\begin{abstract}
During three consecutive years of observation 23 Atlantic cod (Gadus morhua) were tagged with ultrasonic transmitters as part of two experiments to determine the movement patterns of adult cod in the genetically distinctive population inhabiting Gilbert Bay, Labrador. Individual cod were relocated for periods up to 15 months, indicating year-round residency within the bay despite unimpeded access to the open ocean. The tracking data show that individual cod have a strong homing tendency. In experiment 1 displaced cod returned (homed) to their place of capture in a small arm separated from the rest of the bay by a shallow sill while non-displaced fish remained at their capture site. In experiment 2 some cod remained within $2 \mathrm{~km}$ of their capture/release site, a spawning area, while others ranged widely in Gilbert Bay before returning to this site. Whether an individual ranged widely or had more restricted movements was not related to size. Cod exhibited wider ranging movements in the spring and early summer, following spawning, than in the late summer and early autumn. The return of Gilbert Bay cod to specific locations in the inner part of the bay to overwinter and spawn is evidence of one mechanism that could have led to their genetic distinctiveness.
\end{abstract}

\section{INTRODUCTION}

The Atlantic cod (Gadus morhua L.) stock complex off Newfoundland and Labrador once supported the largest fishery for cod in Atlantic Canada. However the stock collapsed and a moratorium on fishing was declared in 1992 (Lear \& Parsons, 1993). Endemic bay stocks were once considered not to exist or of little importance in managing the northern cod fishery (Lilly, 1996). However, the presence of cod in the major bays of northeastern Newfoundland and the continuing near absence of cod on traditional fishing grounds near the edge of the continental shelf (DFO Science Stock Status Report, 1999), has increased scientific interest in the biology of coastal cod. Other than accounts of fishers' knowledge (Munn, 1922; Neis et al., 1995), there has been little written about the life history of cod inhabiting the bays of Labrador.

A historical inshore fishery for cod in Gilbert Bay, southern Labrador (Powell, 1987), prompted us to initiate a study of the movement patterns of individual cod in the area. Our hypothesis was that a resident population of cod exists in the bay, which supported a spring fishery. Ruzzante et al. (2000) found Gilbert Bay cod were distinguishable both genetically and morphometrically from offshore northern cod components and inshore cod from north-east Newfoundland. We predicted that movements of sonically tagged adult cod would show bay residency and homing-to-spawn behaviour which could lead to reproductive isolation as evident in the genetic data.

\section{MATERIALS AND METHODS}

Tracking experiments were conducted on sonically tagged Atlantic cod, ranging in total length from 44 to $70 \mathrm{~cm}$, from October 1996 to March 1999. Both male and female Gilbert Bay cod have reached sexual maturity by this size (Morris, 2000). Fish for tagging were caught by fishing rod and lure in water depths of 3-8 $\mathrm{m}$ and tagged by surgical implantation of VEMCO Ltd V16-4H transmitters. Tags implanted in fish prior to winter freeze up (i.e. October 1996 and November 1997) had a $90 \mathrm{~d}$ delay in activation and a $12 \mathrm{~h}$ on/off cycle to insure that batteries would last through the winter and spring. Tags implanted in spring or summer (1998) were transmitting continuously at the time of tagging. The handling time from capture to release of tagged fish was less than $20 \mathrm{~min}$. When the bay was covered with thick enough ice (January, February and March), a snowmobile was used to locate and track fish. Holes $\sim 1 \mathrm{~km}$ apart were augured through the ice to lower an omnidirectional hydrophone. When a transmitter was detected, a Vemco V-10 directional hydrophone was used to position an ice hole above it or to triangulate its position. Transmitter signals which identified each fish were decoded by a VEMCO VR-60 receiver. Transmitters could usually be detected at $>0.5 \mathrm{~km}$. After the spring melt (early to mid-May), and prior to freeze up (late November), tracking was conducted from a $6 \mathrm{~m}$ outboard motor boat. A directional hydrophone was used to position the boat above a transmitter or to triangulate its position (usually within $<50 \mathrm{~m}$ ). 
Our first experiment (October 1996-July 1997) was designed to test the hypothesis that adult Gilbert Bay cod remain in the bay throughout the winter, and to determine if displaced fish would return to their site of capture in a situation which necessitated their crossing a narrow, shallow sill. Nine cod, $47.5-70 \mathrm{~cm}$ in length, were tagged and released on 6 October 1996 (Table 1). Eight of these fish were from Long Arm and one was from Snook's Arm (Figure 1). Two fish were released at their point of capture in Long Arm, two were released in River Out near the mouth of Long Arm, two were released where River Out and the main arm of Gilbert Bay intersect and two were released in the main arm of Gilbert Bay $\sim 2 \mathrm{~km}$ east of the entrance to River Out towards Peckham Cove (Figure 1). The fish from Snook's Arm was released where captured. Attempts were made to relocate all nine tagged cod beginning in February 1997 and extending to 21 July 1997. The most intensive tracking was done through the ice 26-29 March when all of Gilbert Bay was surveyed, and from a boat between 26-30 May, and between 16-21 July 1997.

The second experiment (November 1997-March 1999) was conducted to provide further evidence that adult cod overwinter in Gilbert Bay, and to provide information on the movement patterns of cod in an area (The Shinneys) where spawning occurs in the bay. Plankton surveys and the examination of mature and spawning cod have provided evidence of spawning activity in The Shinneys (Morris, 2000). It is also a larger and more geographically heterogenous area than either Long Arm or Snook's Arm, and hence provided a better opportunity to study the movement patterns of individual cod. We were interested in the following questions: do adult cod remain in this spawning area following spawning and, if not, do they return to the area prior to the next spawning season?

In an attempt to answer these questions 14 cod ranging in length from $44-62.5 \mathrm{~cm}$ (Table 2) were tagged and tracked. The first four were tagged on 8 November 1997 and the last on 1 August 1998. These cod were caught and released (always at the point of capture) at several sites in the western end of The Shinneys (Figure 1). Tracking commenced in February 1998 and continued until March 1999, by which time all but three of the transmitters were inactive. Tagged fish were located approximately three times per week between 4 June and 12 October, and about once per week to the end of November when ice conditions prevented further tracking in 1998. Oncemonthly trips by snowmobile were made in January, February and March 1999 to locate those tags that were still active. Usually when a fish was located, a depth measurement was made at the site.

A survey of seawater temperature was conducted in Gilbert Bay in July 1996 (Figure 2) with a Seabird Electronics Inc. Seacat SBE 19-03. Some profiles were also taken where fish were captured for sonic tagging and where fish were relocated. To determine the minimum seawater temperature in winter and the timing of vernal warming, a VEMCO Ltd Sealog-TD moored at $5 \mathrm{~m}$ depth in Gilbert Bay recorded temperature every hour during August 1996-May 1998. Two VEMCO Ltd Minilog-Tdata loggers were used to record water temperature hourly for most of the period from June 1998 to November 1999 at depths of 3 and $8 \mathrm{~m}$ in The Shinneys (Figure 3).

\section{RESULTS}

\section{Experiment 1}

Eight of the nine fish sonically tagged on 6 October 1996 were repeatedly located in Gilbert Bay between February and 21 July 1997. Three of the six fish released outside Long Arm were in Long Arm on 1 February 1997, the first attempt to locate them. To home to their capture site in Long Arm they had passed over a narrow $(\sim 50 \mathrm{~m}$ wide), shallow sill covered to a maximum depth of $\sim 0.5 \mathrm{~m}$ at low tide. The sill is located about $1 \mathrm{~km}$ from where Long Arm opens into the River Out (Figure 1). The positions of these three fish, 7 (1104), 8 (1000) and 7 (1008) and the two fish, 10 (1043) and 8 (1100), that had been released in Long Arm, were determined through the ice on 27 and 28 March. On 28 March all five fish were in different locations than on 27 March, and they continued to move during the two hours that their positions were being monitored. The water column was isothermal at $-1.6^{\circ} \mathrm{C}$. Between 26 and 29 May, and again between 16 and 20 July 1997 the presence of these fish in Long Arm was confirmed, as was the fact that all

Table 1. Information on nine Atlantic cod sonically-tagged and released on 6 October 1996 and tracked during experiment 1. Tags became active $90 \mathrm{~d}$ after tagging and had an expected battery life of $\sim 6$ months. Tracking started in February 1997 and the last day of tracking was 20 or 21 July 1997.

\begin{tabular}{|c|c|c|c|c|c|c|}
\hline Fish no. & $\begin{array}{l}\text { Length } \\
(\mathrm{cm})\end{array}$ & $\begin{array}{c}\text { Weight } \\
(\mathrm{g})\end{array}$ & Capture site & Release site & Site of last detection & Date last detected \\
\hline $10(1043)$ & 56.0 & 1750 & Long Arm & Long Arm & Long Arm & $20 / 07 / 97$ \\
\hline $8(1100)$ & 52.0 & 1600 & Long Arm & Long Arm & Long Arm & $20 / 07 / 97$ \\
\hline $7(1104)$ & 58.5 & 1750 & Long Arm & River Out & Long Arm & $20 / 07 / 97$ \\
\hline $9(1031)$ & 61.5 & 2000 & Long Arm & River Out & River Out & $21 / 07 / 97 *$ \\
\hline $8(1000)$ & 56.0 & 1750 & Long Arm & Gilbert Bay & Long Arm & $20 / 07 / 97$ \\
\hline $7(1008)$ & 59.5 & 2200 & Long Arm & Gilbert Bay & Long Arm & $20 / 07 / 97$ \\
\hline $11(1000)$ & 47.5 & 1100 & Long Arm & Gilbert Bay & The Shinneys & $28 / 05 / 97$ \\
\hline $10(1159)$ & 53.5 & 1500 & Long Arm & Gilbert Bay & - & nd \\
\hline $11(1100)$ & 70.0 & 3300 & Snook's Arm & Snook's Arm & Snook's Arm & $21 / 07 / 97$ \\
\hline
\end{tabular}

*, transmitter was stationary after April (see text); nd, no data — transmitter was never detected and may not have become activated. 
Table 2. Information on 14 Atlantic cod sonically-tagged and released in The Shinneys during experiment 2. Tracking commenced in February 1998 and continued until March 1999. Fish were sexed, when possible, by visual inspection of the gonad through the incision made for the tag. Tags used in November 1997 had an expected battery life of $\sim 6$ months. Those used in 1998 had an expected battery life of $\sim 10$ months.

\begin{tabular}{rccccccc}
\hline \multicolumn{1}{c}{ Fish no. } & Length $(\mathrm{cm})$ & Weight $(\mathrm{g})$ & Sex & Tagging Date & Left Shinneys & Where last detected & Date last detected \\
\hline $8(1000)$ & 50.5 & 1043 & $\mathrm{~m}$ & $08 / 11 / 97$ & no & The Shinneys & $20 / 11 / 98 *$ \\
$10(1043)$ & 46.2 & 1116 & $\mathrm{~m}$ & $08 / 11 / 97$ & yes & The Shinneys & $23 / 10 / 98$ \\
$7(1104)$ & 44.0 & 853 & $\mathrm{~m}$ & $08 / 11 / 97$ & yes & The Shinneys & $21 / 01 / 99$ \\
$9(1031)$ & 44.0 & 789 & $\mathrm{f}$ & $08 / 11 / 97$ & yes & Gilbert Bay & $11 / 07 / 98$ \\
$7(1536)$ & 50.8 & - & $\mathrm{f}$ & $05 / 06 / 98$ & no & The Shinneys & $02 / 01 / 99$ \\
$9(1594)$ & 53.8 & - & $\mathrm{m}$ & $05 / 06 / 98$ & yes & The Shinneys & $20 / 11 / 98$ \\
$7(1632)$ & 50.5 & - & $\mathrm{m}$ & $05 / 06 / 98$ & no & The Shinneys & $02 / 01 / 99$ \\
$8(1500)$ & 61.5 & - & $\mathrm{m}$ & $05 / 06 / 98$ & yes & The Shinneys & $01 / 10 / 98$ \\
$9(1500)$ & 50.0 & - & $\mathrm{f}$ & $06 / 06 / 98$ & yes & The Shinneys & $20 / 11 / 98$ \\
$8(1600)$ & 51.0 & - & $\mathrm{f}$ & $06 / 06 / 98$ & yes & River Out & $27 / 11 / 98$ \\
$11(1500)$ & 47.3 & 1137 & $\mathrm{f}$ & $28 / 07 / 98$ & no & The Shinneys & $20 / 02 / 99$ \\
$10(1623)$ & 47.7 & 1000 & - & $28 / 07 / 98$ & no & The Shinneys & $23 / 03 / 99$ \\
$11(1600)$ & 62.5 & - & - & $28 / 07 / 98$ & yes & Gilbert Bay & $23 / 03 / 99$ \\
$10(1507)$ & 50.2 & 1090 & - & $01 / 08 / 98$ & no & The Shinneys & $20 / 02 / 99$ \\
\hline
\end{tabular}

*, transmitter was stationary after May 1998.

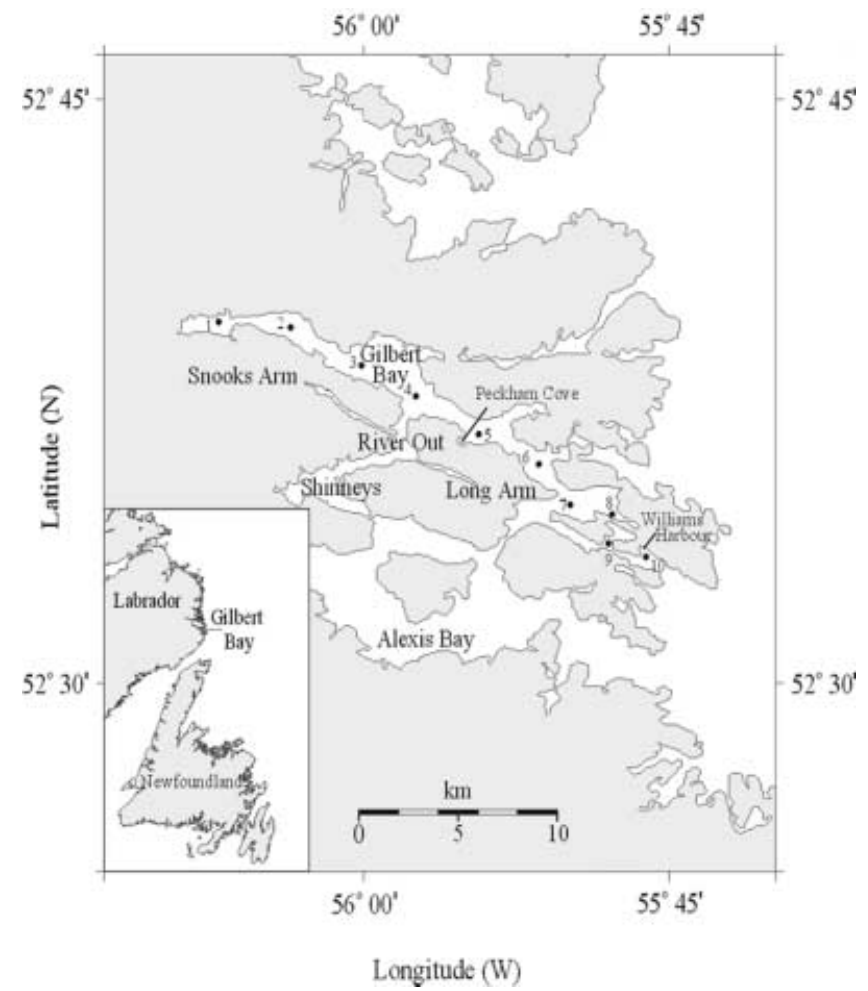

Figure 1. Map of Gilbert Bay, south-eastern Labrador. The Shinneys, Long Arm, Snook's Arm and River Out are parts of the bay where tagged fish were captured and/or released. Station locations for 6 July 1996 vertical temperature profiles running the length of the main arm of Gilbert Bay are numbered $1-10$.

five were active. Rod and line fishing in the immediate vicinity of tagged fish resulted in the capture of cod, but none of the sonically tagged fish. The range in water depth in Long Arm where tagged fish were located was 5-10 m. In May the water temperature was subzero below $3 \mathrm{~m}$ while in July it was $4-10^{\circ} \mathrm{C}$ at the depth of tagged fish.

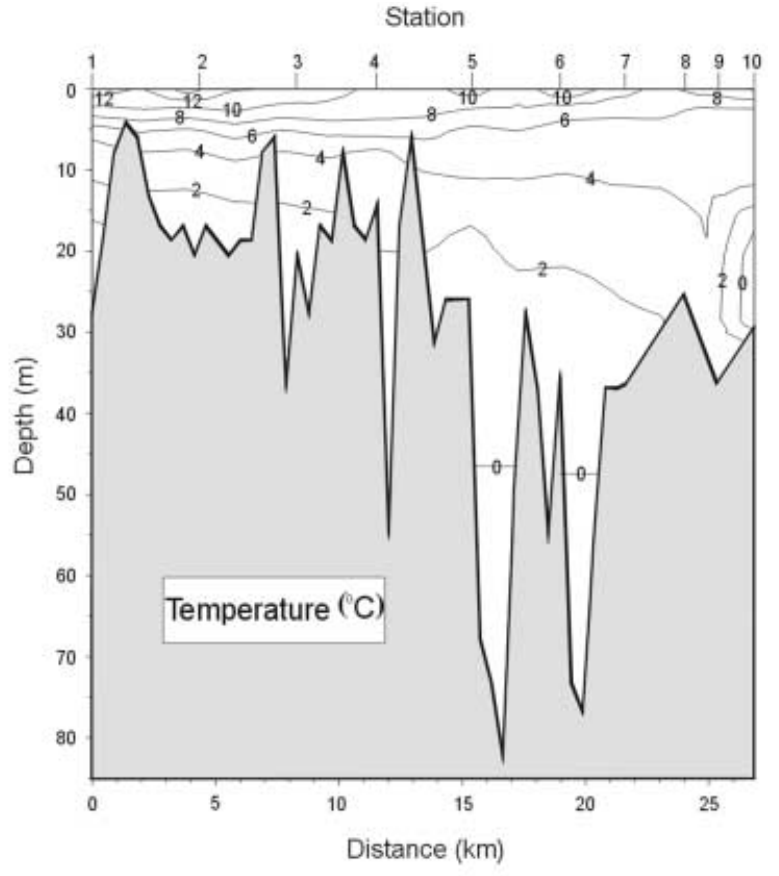

Figure 2. Temperature structure of the water column in Gilbert Bay on 6 July 1996 based on vertical profiles at stations (1-10) shown in Figure 1.

The fish captured and released in Snook's Arm, 11 (1100), remained in Snook's Arm for the duration of tracking (February-July, 1997). Its movements were tracked through the ice for several hours on 27 March during which it moved $\sim 600 \mathrm{~m}$ into a shallow $(<4 \mathrm{~m})$ cove at the top of Snook's Arm and then returned to its original position in slightly deeper $(7-8 \mathrm{~m})$ water in the main channel. The water column was isothermal at $-1.5^{\circ} \mathrm{C}$. In both May (27 and 28) and July (16-19) the movements of the fish were monitored on consecutive days. On several occasions it moved to within $100 \mathrm{~m}$ of the mouth of the arm where it spent up to $30 \mathrm{~min}$ before moving back up the arm. During one tracking period 
lasting four hours it moved the entire length of the arm $(\sim 4 \mathrm{~km})$ making frequent stops and at times doubling back on itself. During these tracking periods the fish was usually close to shore and in water less than $6 \mathrm{~m}$ deep. The bottom temperature at this depth was subzero in May and $4-12{ }^{\circ} \mathrm{C}$ in July.

One of the Long Arm fish released in the main arm of Gilbert Bay, 11 (1000), was located in The Shinneys (Figure 1) on 27 and 28 March during hydrophone surveys through the ice. Between these two dates it had moved a minimum of $2 \mathrm{~km}$ and was moving while being tracked. On both dates it was in 5-8 $\mathrm{m}$ of water. In May (26-28) it was still in The Shinneys where it was located in a shallow $(2-3 \mathrm{~m})$ cove under land fast ice. On 26 May its movements were monitored for several hours, during which it remained under the ice but moved about $100 \mathrm{~m}$ along the shore. Rod and line fishing indicated that it was in an aggregation of actively foraging cod, some of which were partially spent. The water temperature was $3^{\circ} \mathrm{C}$ at the surface but subzero below $3 \mathrm{~m}$. This fish then, based on the results of experiment 2 (see below), presumably moved out of The Shinneys into the main part of Gilbert Bay as it was not located in July in The Shinneys, Long Arm, Snook's Arm or River Out. No attempt was made to locate it in the main channel of Gilbert Bay.

Another transplanted Long Arm fish, 9 (1031), which did not return to Long Arm was located in March in the River Out near the mouth of Long Arm. In April and May this fish was still in the River Out but $\sim 500 \mathrm{~m}$ from its March position. In July it was determined that the transmitter's position was stationary and hence no longer in a live fish. We speculate that this fish was killed by a harbour seal (Phoca vitulina) as several were seen at this site in March when the River Out had the only open water in Gilbert Bay. The one other Long Arm fish tagged on 6 October 1996 and released in Gilbert Bay, 10 (1159) (Table 1) was never detected.

\section{Experiment 2}

The 14 cod tagged with sonic transmitters in The Shinneys were all detected following tagging and most were tracked for periods longer than the predicted battery life (6 or 10 months depending on the transmitter's cycle) of their tag (Table 2). The four fish tagged in the autumn of 1997 remained in The Shinneys throughout the winter of 1997-1998 as determined by through-theice tracking. As observed in experiment 1, these fish were active during winter as indicated by changes in their position between successive locations. One fish, 7 (1104) (Table 2), whose tag continued transmitting longer than expected, was in The Shinneys on 21 January 1999; 15 months, and well into its second winter, after being tagged. This was one of the fish (see below) that moved out of The Shinneys for part of the summer but returned to this spawning area in the early autumn.

Two general patterns of movements were exhibited by the fish tagged in The Shinneys. Six stayed in The Shinneys throughout the tracking period while eight moved into the main part of Gilbert Bay. Of the fish that moved out of The Shinneys, all but three returned there in the late summer or autumn. And of these three, only one, 11 (1600), was known to have spent the winter in the main arm of Gilbert Bay. It was last located on 23 March 1999 near the head of Gilbert Bay close to its November
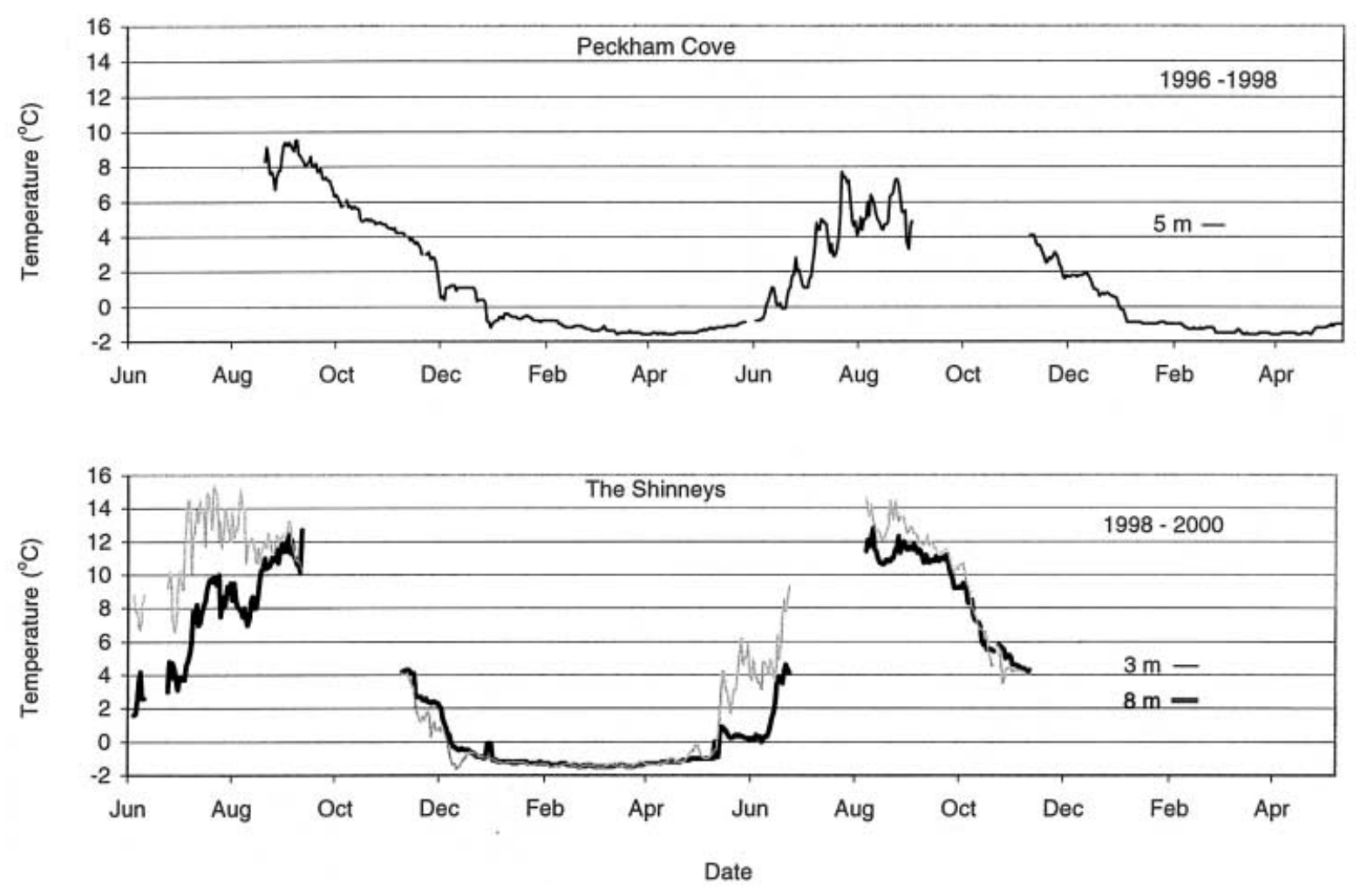

Figure 3. Time series of water temperature at $5 \mathrm{~m}$ depth in Peckham Cove (August 1996-May 1998) and at 3 and $8 \mathrm{~m}$ depth in The Shinneys (June 1998-November 1999). 
1998 and January 1999 positions. One of the other two fish, 9 (1031) (Table 2), was last located in the upper part of Gilbert Bay on 11 July. Given our intensive tracking during July and August, it seems likely that this fish was either caught or that its transmitter malfunctioned. The third fish, 8 (1600), was last located in the River Out near the entrance to The Shinneys. After leaving The Shinneys on 9 June, this fish had been near the mouth of Gilbert Bay until early August when it re-entered the River Out. It was regularly located in the River Out from 10 August to its last detection on 27 November.

Tagged fish, whether in The Shinneys or not, tended to move longer distances between locations in the spring and early summer than in the late summer and autumn. While in The Shinneys, they generally exhibited restricted movements and were in water depths less than $8 \mathrm{~m}$. Water temperature at this depth was above $5^{\circ} \mathrm{C}$ from July to October (Figure 3). Figure 4 shows the range of movement of four fish which stayed in The Shinneys. These fish were usually in water less than $7 \mathrm{~m}$ deep and consequently at a temperature above $8^{\circ} \mathrm{C}$ for the July-October period. Fish which returned to The Shinneys in the late summer or early autumn also restricted their movements to similarly small home ranges, e.g. fish 9 (1594) and 9 (1500) (Figure 5).

There was no apparent relationship between fish size and range of movements although the size range of tagged fish was relatively small (Tables $1 \& 2$ ). The largest fish $(70 \mathrm{~cm})$ stayed in Snook's Arm for the duration of tracking (10 months) while several of the smallest fish were among those which showed wide ranging movements in the main arm of Gilbert Bay. Interestingly, of the four fish tagged in July and August only the largest, $62.5 \mathrm{~cm}$ (Table 2), left The Shinneys. Given when it was tagged, i.e. mid-summer, it may have been a widely ranging fish from another part of the bay and only a temporary resident of The Shinneys at the time of tagging. As mentioned above this was the only tagged fish known to have overwintered in the main arm of Gilbert Bay.
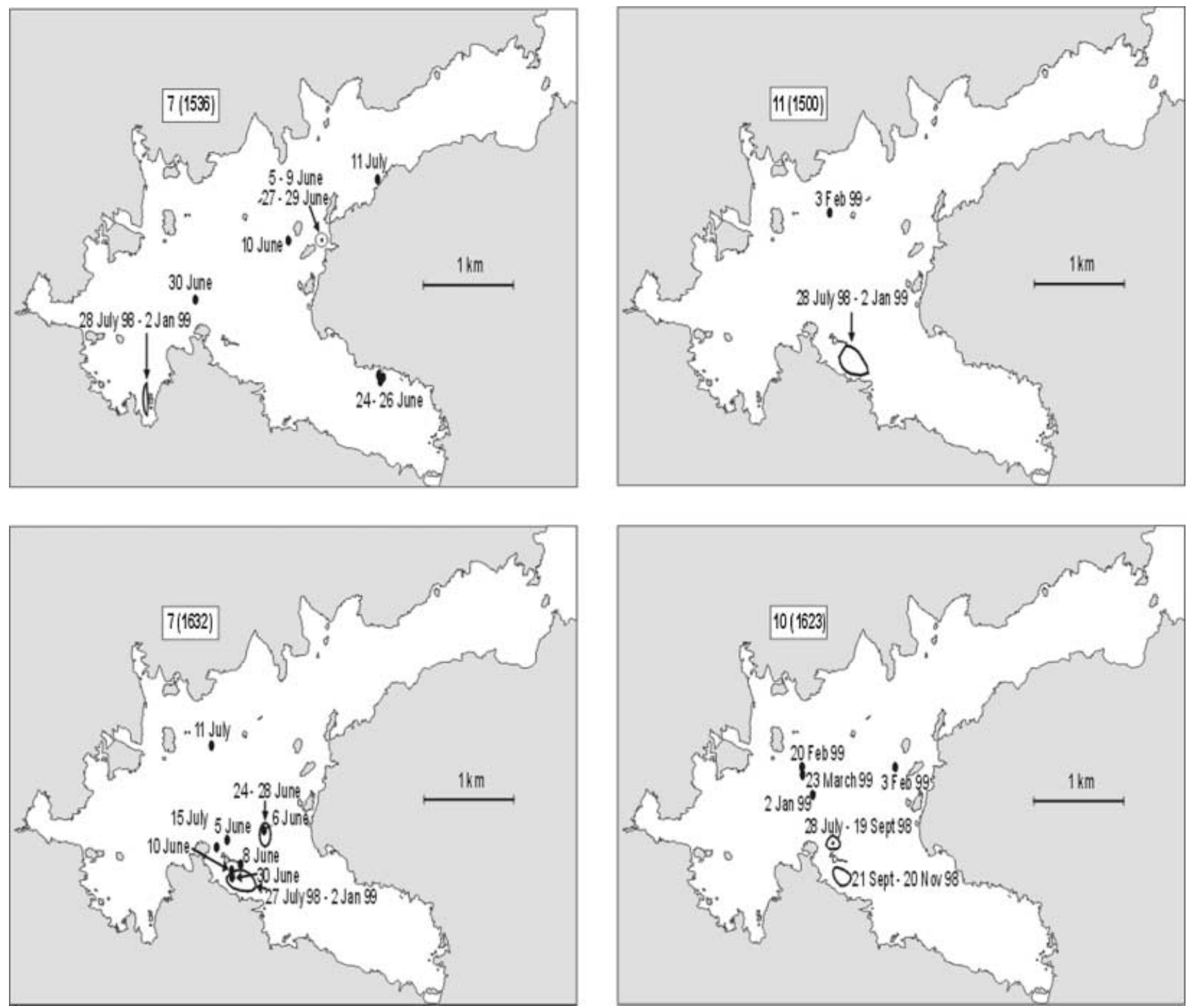

Figure 4. Experiment 2 tracking data for four of six fish that did not leave The Shinneys during tracking. Area enclosed by a line indicates where fish was located for all or most of the period shown. Tagging data for individual fish are presented in Table 2. Earliest date is for site of capture and release. 

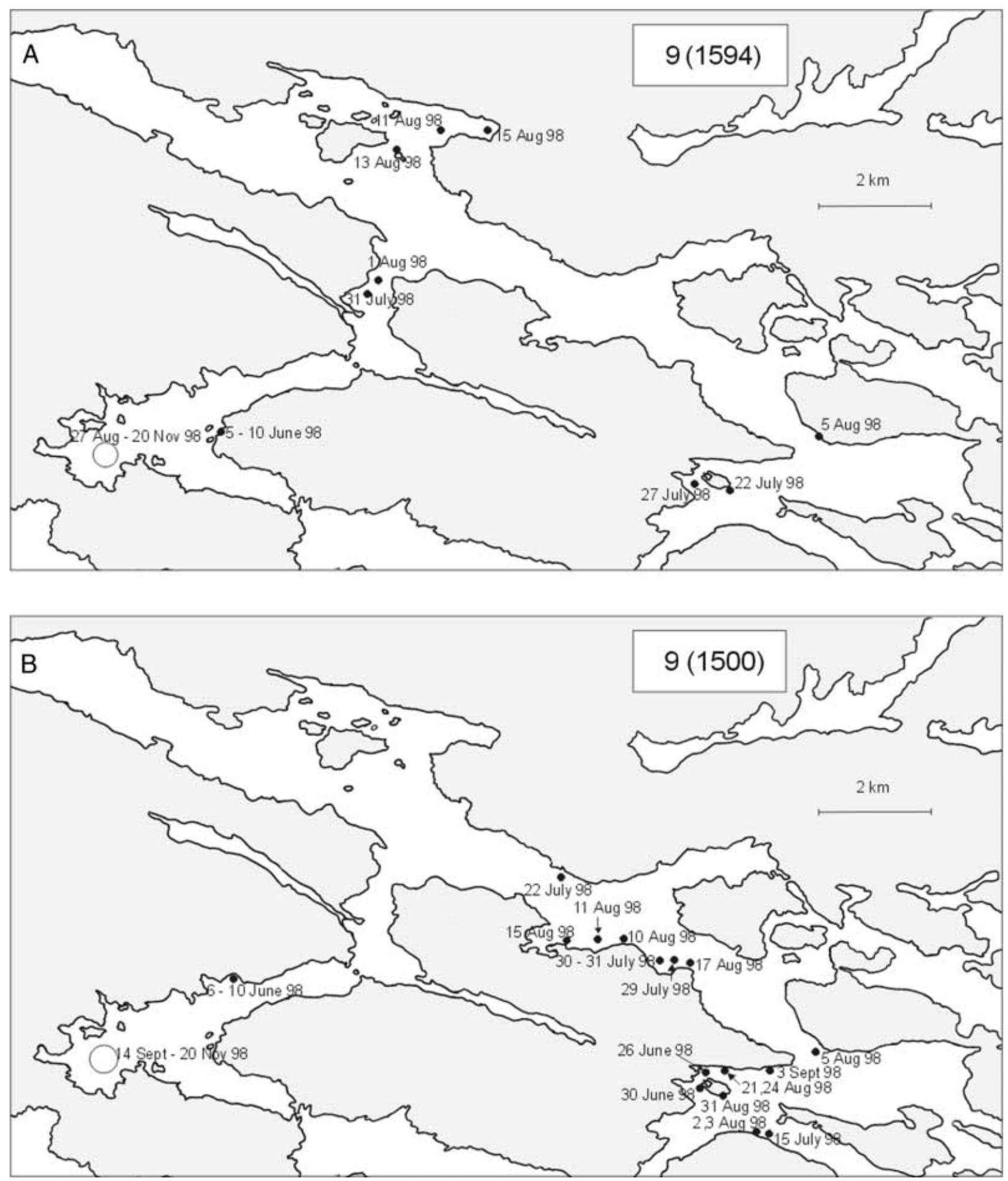

Figure 5. Experiment 2 tracking data for two fish from The Shinneys that ranged widely in Gilbert Bay prior to returning to The Shinneys in the early autumn. Area enclosed by a line indicates where fish was located for all or most of the period shown. Note restricted movements after their return to The Shinneys. Earliest date is site of capture and release. Tagging data for individual fish are presented in Table 2.

Of the tagged cod that moved out of The Shinneys, several restricted their activity to a relatively small area, e.g. fish 7 (1104) and 8 (1500) (Figure 6), while others ranged more widely e.g. fish 9 (1500) and 9 (1594) (Figure 5). In Gilbert Bay tagged fish were generally in deeper and colder water than in The Shinneys. The mean water depth at 72 locations of sonically tagged cod in Gilbert Bay in July and August was $13.5 \mathrm{~m}$ (range of 8-25 m). The temperature at this depth ranged from 2 to $6^{\circ} \mathrm{C}$.

Sex did not seem to be a factor in the range of movements of an individual. Both males and females ranged widely in Gilbert Bay and returned to The Shinneys (Table 2). 

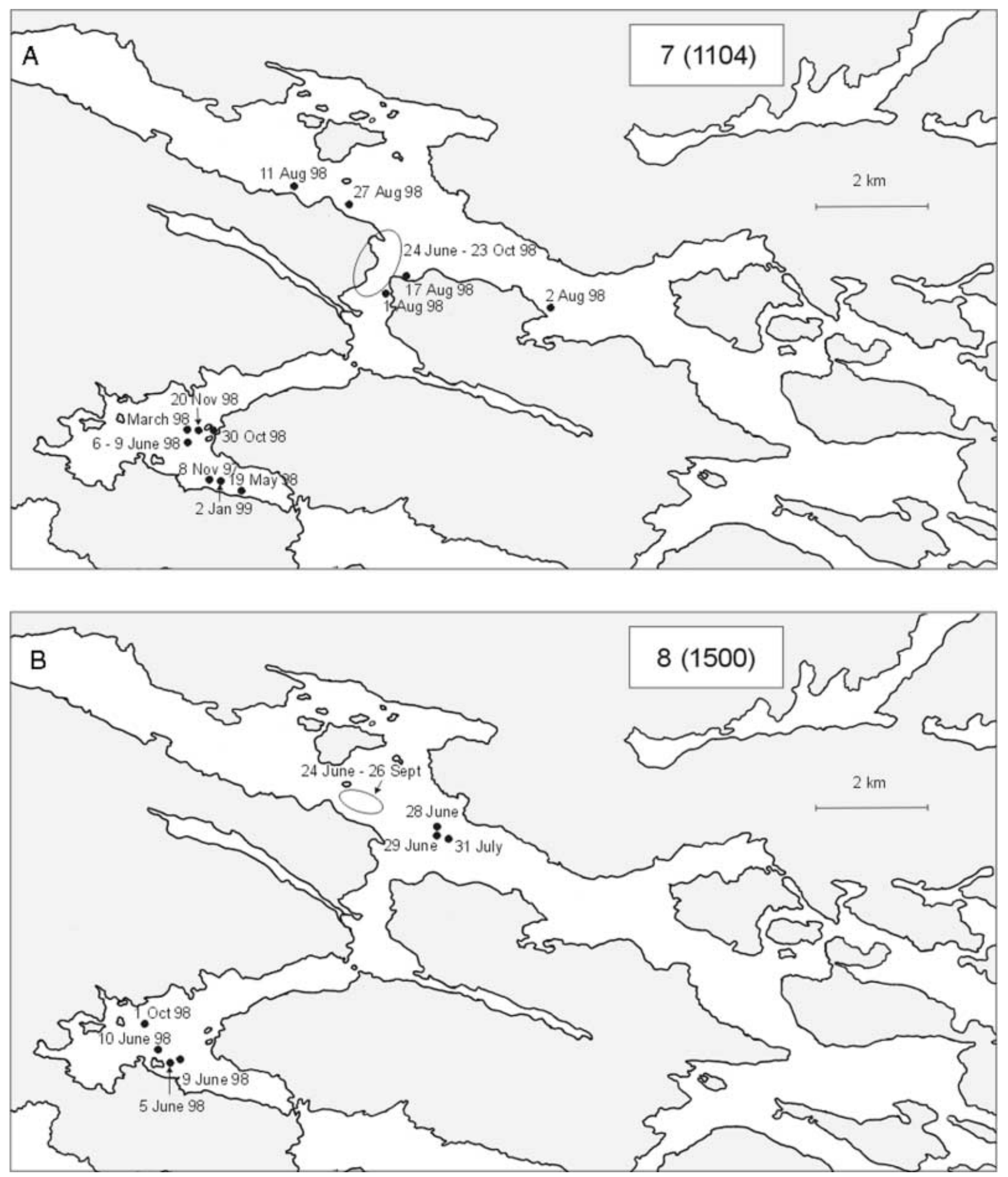

Figure 6. Experiment 2 tracking data for two fish that moved out of The Shinneys but then restricted their movements to relatively small areas before returning to The Shinneys. Area enclosed by a line indicates where fish was located for all or most of the period shown. Earliest date is site of capture and release. Tagging data for individual fish are presented in Table 2.

\section{DISCUSSION}

That adult Atlantic cod overwinter in Newfoundland and Labrador bays has been inferred from tag-recapture studies as well as from winter fishing activity in a number of areas (reviewed by Lilly, 1996). Clark \& Green (1990) used sonic tracking to study the summer and autumn movement patterns of 3-y old juvenile Atlantic cod in Conception Bay, Newfoundland, but the study by Wroblewski et al. (1994) in Trinity Bay was the first to employ sonic tracking to investigate the overwintering behaviour of adult Atlantic cod in a Newfoundland bay. Adult cod tagged in autumn and winter were observed in Trinity Bay until the following spring. During the 
winter they inhabited subzero temperature waters as deep as $150 \mathrm{~m}$. Some of the sonically tagged fish were subsequently recaptured as much as $500 \mathrm{~km}$ from Trinity Bay but it is not known whether such fish would have returned to Trinity Bay, overwintered in another inshore area, or migrated offshore as was typical for much of the northern cod stock (Lear \& Green, 1984). Even so, genetic data (Ruzzante et al., 1996) and physiological evidence (Goddard et al., 1994) suggest that a local population of cod lives year-round in Trinity Bay and spawns inshore in June-July (Smedbol \& Wroblewski, 1997).

The data reported here for Atlantic cod in Gilbert Bay, Labrador, which covers three consecutive years of sonic tracking studies, show that adult Atlantic cod which overwinter in Gilbert Bay reside there throughout the year. All sonically tracked fish stayed in the bay for the duration of tracking which usually included both a winter and summer period. One fish, whose transmitter lasted long enough to provide such information, was in its second winter at its tagging site when its transmitter ceased operating. Most fish also showed fidelity to their capture site. In some cases this involved homing following forced displacement (experiment 1), and in other cases it involved returning to The Shinneys, their site of capture and release, following excursions to other parts of the bay (experiment 2). Other fish showed fidelity to the capture site by remaining there throughout the tracking period (experiments 1 and 2). These data, together with data on reproductive biology and from conventional tagging (Morris, 2000), and genetics (Ruzzante et al., 2000) are convincing evidence of a resident population of Atlantic cod in Gilbert Bay. To our knowledge this is the only population of Atlantic cod in the western North Atlantic with unimpeded access to the open ocean, for which such strong evidence exists that individuals complete their life cycle in a bay.

The tracking data also indicate that individual cod in Gilbert Bay have extensive and detailed spatial information about their environment. The homing of displaced fish to their site of capture which required them to locate and swim through a shallow, narrow channel is evidence of this, as well as indicating that these fish have a strong tendency to home to a familiar site. The direct and rapid movements that non-displaced fish made between frequented sites separated by more than a $\mathrm{km}$ is further evidence of the use of familiar landmarks, as are the rapid and directed movements covering more than $5 \mathrm{~km}$ made by fish both leaving and returning to The Shinneys.

The spatial information (landmarks) necessary for homing and directed movements is presumably acquired during excursions outside of their home area (Dodson, 1988). It is interesting, therefore, that some tagged cod exhibited wide ranging movements while others did not. Although the number of fish observed was limited, neither size (total length) nor sex seemed to be associated with a fish's range of movements. It does appear, however, that fish were more likely to make wide ranging movements in the late-spring to mid-summer than at other times of the year. Spawning occurs in Gilbert Bay in late May and early June (Morris, 2000) so these movements are not directly associated with spawning. They are most likely associated with foraging and the movement to foraging sites away from the spawning area. Whether an individual's size, physiological condition following spawning, or some other factor(s), determines its foraging range in a particular summer, cannot yet be answered.

It is significant that fish which left The Shinneys after the spawning season had returned there prior to winter. This indicates that spawning and overwintering occur in the same area and that fish move to spawning areas well in advance of spawning. It also indicates that fish in Gilbert Bay use the same spawning sites from year to year. For a cod population to exhibit the degree of genetic distinctiveness that has been reported for Gilbert Bay cod (Ruzzante et al., 2000), a mechanism $(\mathrm{s})$ which restricts gene flow between it and contiguous populations is necessary. The return of Gilbert Bay cod to specific spawning sites in the inner part of the bay, and a separation in the time of spawning between Gilbert Bay cod and other cod which migrate to this coastal area in the summer, are likely to be important components of such a mechanism. As mentioned above, Gilbert Bay cod spawn in late May and early June, several months later than the spawning period reported for cod that overwinter offshore on Hamilton Bank (Myers et al., 1993), some of which later migrate to coastal Labrador.

The appearance of offshore cod in Gilbert Bay during the summer is a regular occurrence and at one time supported a local commercial cod fishery (George Rowe, Port Hope Simpson, Labrador, personal communication). Although their numbers are much reduced, some offshore cod still enter Gilbert Bay in the summer. During several tracking sessions when tagged fish were near the mouth of Gilbert Bay we fished over them and caught (based on colour pattern) both offshore and bay fish. Given that both types of fish intermingle and will apparently forage together raises the intriguing and important question as to why bay fish remain in the bay and offshore fish do not. Only through further research on the behaviour of these fish might it be possible to answer this question.

We thank Wade Bailey, Byron Earle, Damien Kippenhuck, Corey Morris, Trent Parr, Jim Russell, and, especially, George Rowe for assistance in the field. The comments of D.H. Steele, Robert Dunbrack and two anonymous referees are very much appreciated. Derek Pritchett and Corey Morris assisted with the illustrations. This research was supported by funding from the Canada-Newfoundland Comprehensive Labrador Cooperation Agreement, the Canadian Centre for Fisheries Innovation in partnership with the Labrador Fishermen's Union Shrimp Company Ltd, and an NSERC operating grant to J.M.G.

\section{REFERENCES}

Clark, D.S. \& Green, J.M., 1990. Activity and movement patterns of juvenile Atlantic cod, Gadus morhua, in Conception Bay, Newfoundland, as determined by sonic telemetry. Canadian Fournal of Zoology, 68, 1434-1442.

Dodson, J.J., 1988. The nature and role of learning in the orientation and migratory behavior of fishes. Environmental Biology of Fishes, 23, 161-182.

DFO, 1999. Science Stock Status Report for Northern Cod A2-01. St John's, Newfoundland: Canada Department of Fisheries and Oceans. 
Goddard, S.V., Wroblewski, J.S., Taggart, G.T., Howse, K.A., Bailey, W.L., Kao, M.H. \& Fletcher, G.L., 1994. Overwintering of adult northern Atlantic cod (Gadus morhua) in cold inshore waters as evidenced by plasma antifreeze glycoprotein levels. Canadian Fournal of Fisheries and Aquatic Sciences, 51, 2834-2842.

Lear, W.H. \& Green, J.M., 1984. Migration of the "northern" Atlantic cod and the mechanisms involved. In Mechanisms of migration in fishes (ed. J.D. McCleave et al.), pp.309-315. New York: Plenum Press.

Lear, W.H. \& Parson, L.S., 1993. History and management of the fishery for northern cod in NAFO Divisions $2 \mathrm{~J}, 3 \mathrm{~K}$ and 3L. In Perspectives on Canadian marine fisheries management (ed. L.S. Parsons and W.H. Lear), pp. 55-89. Ottawa: Department of Fisheries and Oceans. [Canada Bulletin of Fisheries and Aquatic Sciences, vol. 226.]

Lilly, G.R., 1996. Observations on cod in the inshore environment of eastern Newfoundland. North Atlantic Fisheries Organization, SCR doc. 96/59, serial no. N2735.

Morris, C., 2000. Biology of a resident cod (Gadus morhua) population in Gilbert Bay, Labrador. MSc thesis, Memorial University of Newfoundland, St John's, Canada.

Munn, W.A., 1922. 'Annual migration of codfish in Newfoundland waters'. Nerefoundland Trade Review, Dec. 23, 21-24.

Neis, B., Ripley, P. \& Hutchings, J.A., 1995. The "nature" of cod (Gadus morhua): perceptions of stock structure and cod behaviour by fishermen, "experts" and scientists, the 19th century to the present. In Marine resources and human societies in the North Atlantic since 1500 (ed. D. Bickers), pp. 123-188. St John's, Newfoundland: Memorial University of Newfoundland. [ISER Conference Papers, no. 5.]
Powell, B.W., 1987. The letter that was never read (a history of the Labrador fishery). St John's, Newfoundland: Good Tidings Press.

Myers, R.A., Mertz, G. \& Bishop, G.A., 1993. Cod spawning in relation to physical and biological cycles of the northern northwest Atlantic. Fisheries Oceanography, 2, 154-165.

Ruzzante, D.E., Taggart, C.T., Cook, D. \& Goddard, S., 1996. Genetic differentiation between inshore and offshore Atlantic cod (Gadus morhua L.) off Newfoundland: microsatellite DNA variation and antifreeze level. Canadian Journal of Fisheries and Aquatic Sciences, 53, 634-645.

Ruzzante, D.E., Wroblewski, J.S., Taggart, C.T., Smedbol, R.K., Cook, D. \& Goddard, S.V., 2000. Bay-scale population structure in coastal Atlantic cod in Labrador and Newfoundland, Canada. Fournal of Fish Biology, 56, 431-447.

Smedbol, R.K. \& Wroblewski, J.S., 1997. Evidence for inshore spawning of northern Atlantic cod (Gadus morhua) in Trinity Bay, Newfoundland, 1991-1993. Canadian Fournal of Fisheries and Aquatic Sciences, 54, (Supplement 1), 177-186.

Wroblewski, J.S., Bailey, W.L. \& Howse, K.A., 1994. Observations of adult Atlantic cod (Gadus morhua) overwintering in nearshore waters of Trinity Bay, Newfoundland. Canadian Fournal of Fisheries and Aquatic Sciences, 51, 142-150. 